\title{
Pemetaan Risiko Penyakit Tuberkulosis (TBC) di Kota Surakarta dengan Spatial Empirical Bayes
}

\author{
Husna Afanyn Khoirunissa ${ }^{1}$ \\ ${ }^{1}$ Program Studi Statistika, Fakultas MIPA, Universitas Sebelas Maret \\ husnafanyn@gmail.com
}

\begin{abstract}
Tuberculosis is an infectious disease that can attack human with a poor immune system. In 2017, there were 723 residents of Surakarta tested positive for tuberculosis. The spatial empirical Bayes method is a good method for mapping the risk of tuberculosis because this method includes spatial dependency information and can overcome small area problems. This method can help the prevention of tuberculosis in Surakarta. In the analysis, it was found that the number of cases of tuberculosis in Surakarta has a spatial dependency that has an impact of the spread of tuberculosis. Sub-district classification with the highest risk value is Jebres, Tegalharjo, Jajar, Laweyan, Sondakan, Purwosari, Mangkubumen, Keratonan, Timuran, and Punggawan.
\end{abstract}

Keywords : tuberculosis, mapping, spatial empirical Bayes, Surakarta

\section{Pendahuluan}

Tuberkulosis merupakan penyakit menular yang dapat menyerang orang dengan sistem kekebalan tubuh yang buruk. Pada tahun 2017, Dinas Kesehatan Kota Surakarta mencatat sebanyak 723 warga Kota Surakarta dinyatakan positif tuberkulosis [1]. Dalam menunjang upaya preventif penanggulangan sebaran tuberkulosis di Kota Surakarta, diperlukan suatu analisis yang dapat memberikan informasi mengenai kondisi terkini tentang jumlah kasus tuberkulosis di setiap kelurahan di Kota Surakarta. Pemetaan dan pemodelan risiko penyakit tuberkulosis di Kota Surakarta diperlukan guna mengetahui sebaran risiko penyakit tuberkulosis agar penanggulangan dapat dilakukan secara efisien. Metode yang dapat digunakan untuk memetakan dan memodelkan risiko penyebaran penyakit tuberkulosis salah satunya adalah metode spasial. Metode spasial dapat mengetahui adanya ketergantungan spasial dalam penyebaran penyakit tuberkulosis. Model Spatial Empirical Bayes merupakan model yang baik dalam memodelkan risiko penyebaran penyakit tuberkulosis karena model ini menyertakan informasi ketergantungan spasial dan dapat mengatasi masalah small area atau wilayah dengan angka kasus kecil [2].

Penelitian tentang pemetaan menggunakan Empirical Bayes Estimator pernah dilakukan oleh Roger dan Marshall [3]. Dalam penelitian yang menggunakan studi kasus kematian bayi di Auckland, New Zealand tersebut disimpulkan bahwa, estimator 
menggunakan pola spasial memberikan performasi estimator lebih baik dibanding dengan estimator global menurut total MSE yang diberikan pada masing-masing estimator. Pada penelitian ini, akan dilakukan pemodelan dan pemetaan risiko penyakit tuberkulosis menggunakan Spatial Empirical Bayes dengan studi kasus angka penderita tuberkulosis di masing-masing kelurahan di Surakarta pada tahun 2018.

\section{Landasan Teori}

2.1. Tuberkulosis. Tuberkulosis merupakan penyakit menular langsung yang disebabkan oleh kuman Mycobacterium tuberculosa. Penyakit ini ditularkan melalui droplet nuclei (udara) saat seorang penderita tuberkulosis sedang batuk. Risiko penularan setiap tahun (Annual Risk of Tuberculosis Infection/ ARTI) di Indonesia dianggap cukup tinggi, antara 1 - 3\%. Pada wilayah dengan ARTI sebesar 1\% berarti dalam setiap tahunnya diantara 1000 penduduk, terdapat 10 orang yang akan terinfeksi. Namun, hanya sekitar 10\% dari yang terinfeksi yang akan menjadi penderita tuberculosis [4].

2.2. Analisis Data Spasial. Analisis data spasial merupakan suatu analisis data yang memuat informasi "lokasi" yang menunjukkan lokasi dimana data tersebut berada. Data spasial dapat berupa informasi lokasi geografi, seperti letak garis lintang dan bujur dari masing-masing wilayah dan perbatasan antar daerah. Dalam bentuk lain, data spasial dapat dinyatakan dalam bentuk grid koordinat yang disajikan dalam bentuk peta ataupun piksel seperti bentuk citra satelit. Dengan demikian, pendekatan analisis data spasial biasa disajikan dalam bentuk peta tematik.

2.3. Matriks Pembobot Spasial. Matriks pembobot spasial digunakan untuk menentukan bobot antar lokasi yang diamati berdasarkan letak lokasi terdekat. Menurut Kosfeld pada grid umum terdekat dapat didefinisikan dalam beberapa cara, yaitu:

a. Rook continguity. Rook continguity merupakan matriks pembobot spasial dengan daerah pengamatannya ditentukan berdasarkan sisi-sisi yang saling bersinggungan dan sudut tidak diperhitungkan.

b. Bishop continguity. Bishop continguity merupakan matriks pembobot spasial dengan daerah pengamatannya ditentukan berdasarkan sudut-sudut yang saling bersinggungan dan sisi tidak diperhitungkan.

c. Queen continguity. Queen continguity merupakan matriks pembobot spasial dengan daerah pengamatannya ditentukan berdasarkan sisi-sisi yang saling bersinggungan dan sudut juga diperhitungkan [5]. 
Menurut Kosfeld, matriks pembobot spasial W dapat diperoleh dari dua cara, yaitu matriks pembobot spasial terstandarisasi dan matriks pembobot spasial tak terstandarisasi [5]. Matriks terstandarisasi merupakan matriks pembobot yang diperoleh dengan cara memberikan bobot yang sama rata terhadap daerah terdekat dan yang lainnya nol sedangkan matriks pembobot spasial tak terstandarisasi merupakan matriks pembobot yang diperoleh dengan cara memberikan bobot satu bagi daerah terdekat dan yang lainnya nol.

2.4. Autokorelasi Spasial. Eksplorasi autokorelasi spasial menggunakan plot sebaran Indeks Moran untuk menvisualisasikan besarnya dan rentang autokorelasi spasial. Statistik Moran adalah indikator untuk autokorelasi spasial secara global. Observasi pada lokasi ke- $i$, dinyatakan sebagai $z_{i}=x_{i}-\bar{x}$, dengan $\bar{x}$ adalah rata-rata dari variabel $x$. Statistik Indeks Moran dituliskan dalam persamaan (1).

$I=\frac{\sum_{i} \sum_{j} w_{i j} z_{i}, z_{j} / S_{0}}{\sum_{i} z_{i}^{2} / n}$

dengan $w_{i j}$ merupakan elemen dari matriks pembobot spasial, $S_{0}=\sum_{i} \sum_{j} w_{i j}$ sebagai jumlahan dari pembobot secara keseluruhan, dan $n$ merupakan jumlah dari observasi [6].

2.5. Pemodelan Spatial Empirical Bayes. Model ini merupakan model yang mengatasi permasalahan small area atau small number [2]. Metode ini digunakan dengan cara menarik risiko yang tinggi dan rendah ke nilai rata-ratanya sehingga terdapat pemulusan pada risiko relatif. Pembobot spasial digunakan untuk memasukkan informasi spasial yang dapat menaksir risiko apabila terdapat ketergantungan spasial. Statistik Spatial Empirical Bayes diformulasikan pada persamaan (2):

$\hat{\theta}_{i}^{w}=\frac{\sum_{j} w_{i j} y_{j}+\alpha}{\sum_{j} w_{i j} N_{j}+\beta} ; i=1, \ldots, n$

dengan $y_{i}$ menyatakan angka kasus, $N_{i}$ menyatakan ukuran populasi berisiko pada lokasi ke- $i$, serta $\hat{\theta}_{i}{ }^{w}$ merupakan ukuran Spatial Empirical Bayes dimana parameter $\alpha$ merupakan parameter shape dan parameter $\beta$ merupakan parameter rate yang umumnya ditentukan sama dengan 1 dan $\sum_{j} w_{i j}$ merupakan elemen dari matriks pembobot spasial [7].

\section{Hasil dan Pembahasan}

3.1. Analisis Deskriptif. Data yang digunakan adalah data jumlah penderita penyakit tuberkulosis di masing-masing kelurahan di Kota Surakarta pada tahun 2018 [8]. Untuk 
mendukung pemetaan risiko penyakit, digunakan pula data jumlah penduduk di masingmasing kelurahan di Kota Surakarta pada tahun 2018 sebagai ukuran populasi di masingmasing daerah. Penderita tuberkulosis di Kota Surakarta memiliki rata-rata sebesar 9,157 atau sebanyak 9 penderita di setiap kelurahannya. Penderita terbanyak berada di Kelurahan Jebres sebanyak 69 penderita sedangkan Kelurahan Kepatihan Kulon, Kampung Sewu, dan Kestalan tidak memiliki penderita tuberkulosis.

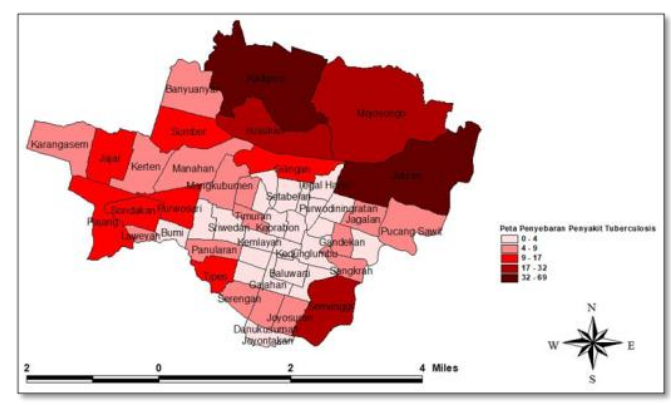

Gambar 1. Peta Penyebaran Penderita Penyakit Tuberkulosis

Gambar 1 menunjukkan peta penyebaran jumlah penderita penyakit tuberkulosis setiap kelurahan di Kota Surakarta pada tahun 2018. Kelurahan dengan jumlah penderita terbanyak (warna merah tertua), yaitu di atas 32 penderita antara lain Kelurahan Kadipiro dan Jebres sedangkan kelurahan dengan jumlah penderita paling sedikit (warna merah muda) yaitu Kelurahan Bumi, Sriwedari, Kemlayah, Kedunglumbu, Baluwarti, Gajahan, Setabelan, Tegal Harjo, Purwodiningratan, dan Baluwarti.

3.2. Uji Autokorelasi Indeks Moran (Autokorelasi secara Global). Indeks Moran menvisualisasikan besarnya dan rentang autokorelasi spasial. Nilai Indeks Moran digunakan untuk identifikasi autokorelasi spasial secara global. Global autokorelasi menyatakan autokorelasi untuk keseluruhan kelurahan di Kota Surakarta.

a. Hipotesis

$\mathrm{H}_{0}: I=0$, tidak terjadi autokorelasi spasial pada model

$\mathrm{H}_{1}: I \neq 0$, terjadi autokorelasi spasial pada model

b. Tingkat signifikansi : $\alpha=1 \%$

c. Daerah Kritis: H0 ditolak jika p-value $<1 \%$

d. Statistik Uji

Pada Gambar 2 menunjukkan output perhitungan menggunakan software Geoda, didapatkan bahwa p-value Indeks Moran sebesar 0,00326 dan nilai Indeks Moran sebesar 0,2447 . 


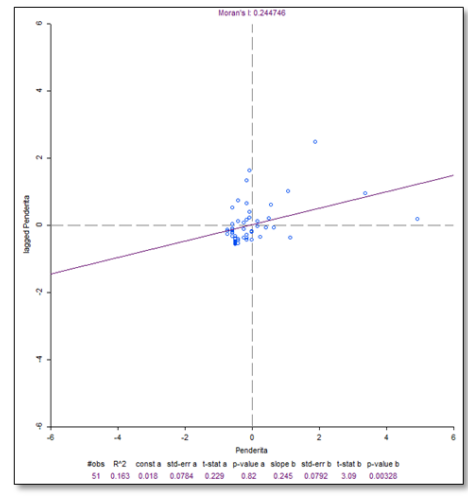

Gambar 2. Scatter plot Indeks Moran

e. Kesimpulan: karena $p$-value $=0,00326$ kurang dari $1 \%$ maka $\mathrm{H}_{0}$ ditolak sehingga dapat diartian bahwa terdapat autokorelasi spasial secara global pada data kasus tuberkulosis.

3.3. Local Moran's Index (LISA). Autokorelasi lokal digunakan untuk mengetahui lokasi-lokasi mana saja yang memiliki kemiripan nilai risiko dan juga digunakan unutk mendukung penentuan model dalam menaksir risiko relatif.

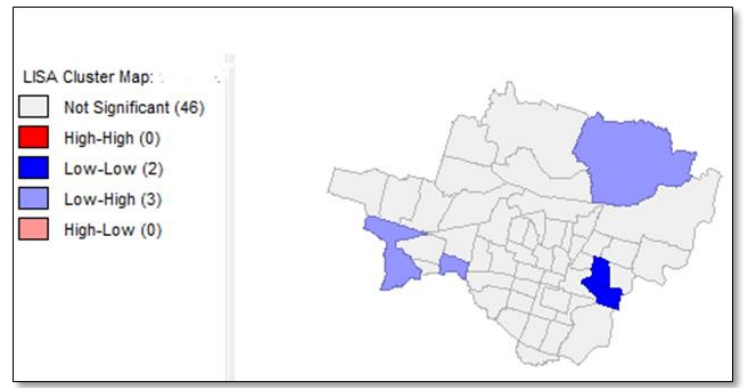

Gambar 3. Peta klasterisasi nilai autokorelasi lokal

Peta klasterisasi pada Gambar 3 menunjukkan bahwa 46 kelurahan termasuk dalam klaster yang tidak signifikan pada nilai autokorelasinya sehingga dapat diartikan bahwa ke-46 kelurahan tersebut tidak terjadi autokorelasi lokal pada kelurahan-kelurahan tersebut atau adanya kasus tuberkulosis pada kelurahan-kelurahan tersebut tidak dipengaruhi oleh daerah di sekitarnya. Kelurahan Gandekan dan Sangkrah termasuk dalam klaster Low-Low yang menunjukkan bahwa kasus tuberkulosis pada kelurahan tersebut rendah (sedikit) dan dikelilingi oleh kelurahan yang memiliki kasus yang sedikit pula. Klaster Low-High merupakan klaster yang menunjukkan bahwa kasus tuberkulosis pada kelurahan tersebut sedikit namun dikelilingi oleh kelurahan yang memiliki kasus yang tinggi. Pada klaster tersebut berisi Kelurahan Jebres, Pajang, dan Bumi. 
3.4. Pemodelan Spatial Empirical Bayes. Pemodelan jumlah penderita penyakit tuberkulosis menggunakan data angka kasus dan melibatkan data ukuran populasi sebagai pembanding. Pembobot spasial yang digunakan dalam pemodelan ini adalah menggunakan pembobot spasial queen contiguity karena pembobot ini memperhitungkan sisi dan sudut yang bersinggungan sehingga lebih akurat dibanding dengan pembobot spasial rook dan bishop contiguity yang masing-masing memperhitungkan persinggungan sisi atau sudut saja. Pada pemodelan ini digunakan metode yang berguna untuk menarik risiko yang tinggi dan rendah ke nilai reratanya sehingga terdapat pemulusan pada risiko relatif, tetapi dengan mempertimbangkan informasi spasial. Taksiran Spatial Empirical Bayes dapat dipetakan menjadi empat kelas (kuantil) berdasarkan nilai $\hat{\theta}_{i}{ }^{w}$ terurut dari terkecil sampai terbesar seperti pada Gambar 4.

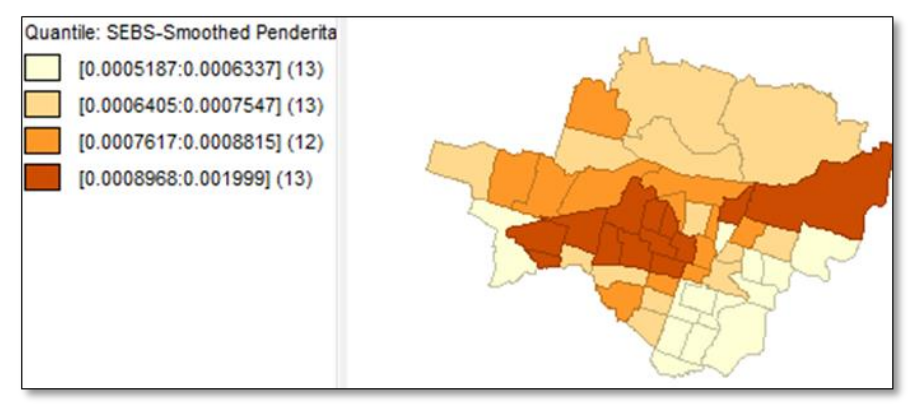

Gambar 4. Peta taksiran Spatial Empirical Bayes

Pada pemetaan risiko berdasarkan kuantil pada Gambar 4, warna paling gelap menunjukkan kelas dengan nilai risiko penyakit yang tinggi, yaitu terdapat 13 kelurahan, antara lain: Jebres, Tegalharjo, Jajar, Laweyan, Sondakan, Purwosari, Mangkubumen, Penumping, Sriwedari, Ketelan, Keratonan, Timuran, dan Punggawan.

\section{Kesimpulan}

Berdasarkan analisis diperoleh bahwa angka kasus penyakit tuberkulosis di Kota Surakarta memiliki autokorelasi spasial/ ketergantungan antar wilayah. Adanya ketergantungan spasial berdampak pada penyebaran penyakit tuberkulosis yang merupakan penyakit menular. Kelas klasifikasi dengan nilai risiko yang paling tinggi, yaitu Jebres, Tegalharjo, Jajar, Laweyan, Sondakan, Purwosari, Mangkubumen, Penumping, Sriwedari, Ketelan, Keratonan, Timuran, dan Punggawan. Model Spatial Empirical Bayes merupakan model yang cocok dalam memetakan dan memodelkan risiko penyakit tuberkulosis karena model ini menyertakan informasi ketergantungan spasial dan dapat mengatasi masalah small area atau wilayah dengan angka kasus kecil. 


\section{Daftar Pustaka}

[1] Dinas Kesehatan Kota Surakarta. Profil Kesehatan Kota Surakarta tahun 2017. Sukarta. Dinas Kesehatan Kota Surakarta. 2018.

[2] Jaya, I.N.M, Tantular, B., dan Zulhanif. Optimalisasi GeoDa dalam Pemodelan dan Pemetaan Penyakit di Kota Bandung. Bandung. Unpad Repository. 2017.

[3] Roger, J.M. Mapping Disease and Mortality Rates using Empirical Bayes Estimators. Journal of the Royal Statistical Society Series C (Applied Statistics). DOI: $10.2307 / 2347593.1991$.

[4] Departemen Kesehatan Republik Indonesia. Pedoman Nasional Penanggulangan Tuberkulosis. Departemen Kesehatan Republik Indonesia. Jakarta. 2008.

[5] Kosfeld, R. Spatial Econometrics. https://www.uni-kassel.de/fb07/fileadmin/ datas/fb07/5-Institute/IVWL/Kosfeld/lehre/spatial/SpatialEconometrics1.pdf, diakses pada tanggal 13 Maret 2020.

[6] Anselin, L. The Moran Scatterplot as an ESDA Tools to Assess Local Instability in Spatial Association. London. 1996.

[7] Anselin, L., Lozano, N., Koschinsky, J. Rate Transformations and Smoothing. Urbana. University of Illinois. 2006.

[8] Dinas Kesehatan Kota Surakarta. Profil Kesehatan Kota Surakarta tahun 2018. Sukarta. Dinas Kesehatan Kota Surakarta. 2019. 